\title{
Detect the Infection with Rubella Virus and Toxoplasmosis in Pregnancy Cases Suffering from Early Abortion by Using Real Time PCR
}

\author{
Mohammed Ayyed Najm ${ }^{1}$, Hadeel Abdelelah Abdel Razaak ${ }^{2}$, HayfaaMahmood Fahad ${ }^{3}$ \\ ${ }^{1}$ Faculty of Pharmacy, Al-Rafidain University College, Baghdad-Iraq, ${ }^{2}$ University of Anbar / College of Science / \\ Department of Biology, ${ }^{3}$ College of Medicine /AL Iraqia University
}

\begin{abstract}
Congenital infections may cause fetal death or newborns with brain malformations, little information is available about the but the impact of these diseases on the outcome of pregnancy. In this study we tested the IgG and IgM antibodies for both Toxoplasma gondii and Rubella. among 58 pregnant women with abortion. and in order to differentiate between the serological and molecular detection methods the samples were alsotested for both Toxoplasma gondii and Rubella by RT-PCR. The results showed that there is a positive relation between the infection with rubella and the infection with toxoplasma $(\mathrm{p}=0.022$, Odd $=4.9)$ and this co-infection attribute to abortion in women. and these results of RT-PCR were significantly different than those with ELISA test.
\end{abstract}

Keyword: Toxoplasma gondii, pregnancy, abortion, newborns, brain malformations

\section{Introduction}

Birth defects are one of the most urgent global health problems affecting millions of births worldwide, but the causes remains unconfirmed ${ }^{[1]}$. Genetic and environmental factors have been found to cause these defects ${ }^{[2]}$. Congenital infections such as toxoplasmosis and rubella are known to play a non-negligible role in the development of brain malformations ${ }^{[3]}$.

Toxoplasmosis is caused by the obligate intracellular protozoan Toxoplasma gondii. It is one of the most prevalent chronic infections affecting one third of the world's human population ${ }^{[4]}$. Toxoplasma gondii infections can cause to a more serious progression when accompanied with some other infection such as HIV and HBV ${ }^{[5]}$.Congenital infections such as toxoplasmosis and rubella are known to play a non-negligible role in the development of brain malformations ${ }^{[6]}$. Toxoplasma gondiiseropositivity and coinfection with TORCH pathogens have been investigated in Qatar with the intention of testing the patients who are considered to be in the high risk group for TORCH pathogens ${ }^{[7]}$. Primary infections of toxoplasmosis, CMV, rubella and HSV during pregnancy can bring wide ranges of clinical symptoms dependent on the stage of pregnancy.
TORCH infections during the early stages of pregnancy may result in congenital malformations, intrauterine growth restriction (IUGR) or fetal death ${ }^{[8]}$.

Rubella infection during pregnancy has a devastating consequence; defined as congenital rubella syndrome (CRS). Miscarriage and stillbirth is the most important sequel of CRS ${ }^{[9]}$

\section{Material and Method}

Subjects:

This study was performed among 68 pregnant women collected from maternity unit at Al-Yarmook teaching hospital in Baghdad, Iraq, from 2018 to 2019. These samples were categorized into two groups, first group include 34 women with spontaneous abortion the other 34 women with normal delivery were enrolled as the control group.A questionnaire including demographic, epidemiological criteria and clinical symptoms was recorded in both the case and control groups by interview.

Five milliliters of venous blood samples were collected from each pregnant woman. Serum were separated from the blood samples and stored at $-20{ }^{\circ} \mathrm{C}$ until use. 


\section{Serological evaluation}

Specific IgG and IgM antibodies to Toxoplasma gondii and Rubella were measured by the Enzyme-linked immunosorbent assay, with commercial ELISA kits (ab108778 -Anti-Toxoplasma gondiiIgM) according to the manufacturer's instructions and the optical density (OD) was read at $450 \mathrm{~nm}$ by the spectrophotometer ELISA reader (Awareness Technology INC Stat Fax2100). Diagnostic criteria IgG and IgM was defined the upper limit of the standard $10 \mathrm{U} / \mathrm{mL}$ (Cut-off).

\section{Nucleic acid extraction}

DNA and RNA were extracted from Toxoplasma gondii and Rubella, respectively using (RIBO-sorb, K2-1-Et-50-CE, Italy) according to the manufacturing procedure.

\section{RT-PCR for detection of viruses}

Both viruses Toxoplasma gondii and Rubella were detected by using commercial RT-PCR kits that allow the qualitative detection of viral nucleic acids in plasma, Toxoplasma gondii Real-TM (Sacae, CAT\#TP150FRT, Italy) for Toxoplasma gondii and Real-TM Qual (Sacace, CAT\#V24-50FRT, Italy) for Rubella.

\section{Statistical Analysis}

All data were analyzed by SPSS version 11.5 (SPSS, Chicago, IL, USA) using Fisher exact test. The odd ratio $(\mathrm{OR})$ and $P$-value were also calculated

\section{Results}

The difference in age between case and control groups wasn't statistically significant, As shown in Table 1. Also the contact with cats showed no statistically significant differences

Table (1): The difference in age between case and control

\begin{tabular}{|l|l|l|l|l|}
\hline Risk factors & Variables & Case $(\mathbf{n}=\mathbf{3 4})$ & control $(\mathbf{n}=\mathbf{3 4})$ & P-value \\
\hline Age & $<20$ & 2 & 1 & 0.5 \\
\hline & $20-40$ & 29 & 30 & \\
\hline & $>41$ & 4 & 3 & \\
\hline Contact to cat & yes & 9 & 7 & 0.6 \\
\hline & no & 25 & 27 & \\
\hline
\end{tabular}

ToxoplasmagondiiIgGantibodywasdetectedin 19(55.8\%) of caseand 11(32.3\%)ofcontrolgroup(OR=1.23, $\mathrm{P}=0.5)$. Rubella IgG antibody was detected in $75.3 \%$ versus $86.7 \%$ in case and control groups $(\mathrm{OR}=0.46, \mathrm{P}=0.05)$. Table (2): The comparison results Toxoplasma gondiiIgG antibody and Rubella

\begin{tabular}{|l|l|l|l|l|}
\hline Infection type & Case & Control & OR & p-value \\
\hline Toxoplasma gondii & $19(55.8 \%)$ & $11(32.3 \%)$ & 1.23 & 0.53 \\
\hline Rubella & $25(75.3 \%)$ & $29(86.7 \%)$ & 1.4 & 0.32 \\
\hline Toxoplasma gondii+ Rubella & $16(47.0 \%)$ & $2(5.8 \%)$ & 4.6 & 0.001 \\
\hline
\end{tabular}

The detection of both viruses were also done by using RT-PCR and the resulted curves showed in figure-1 and the resulted data were compared to data obtained by using ELISA detection method. The comparison results summarized in table- 2 . 


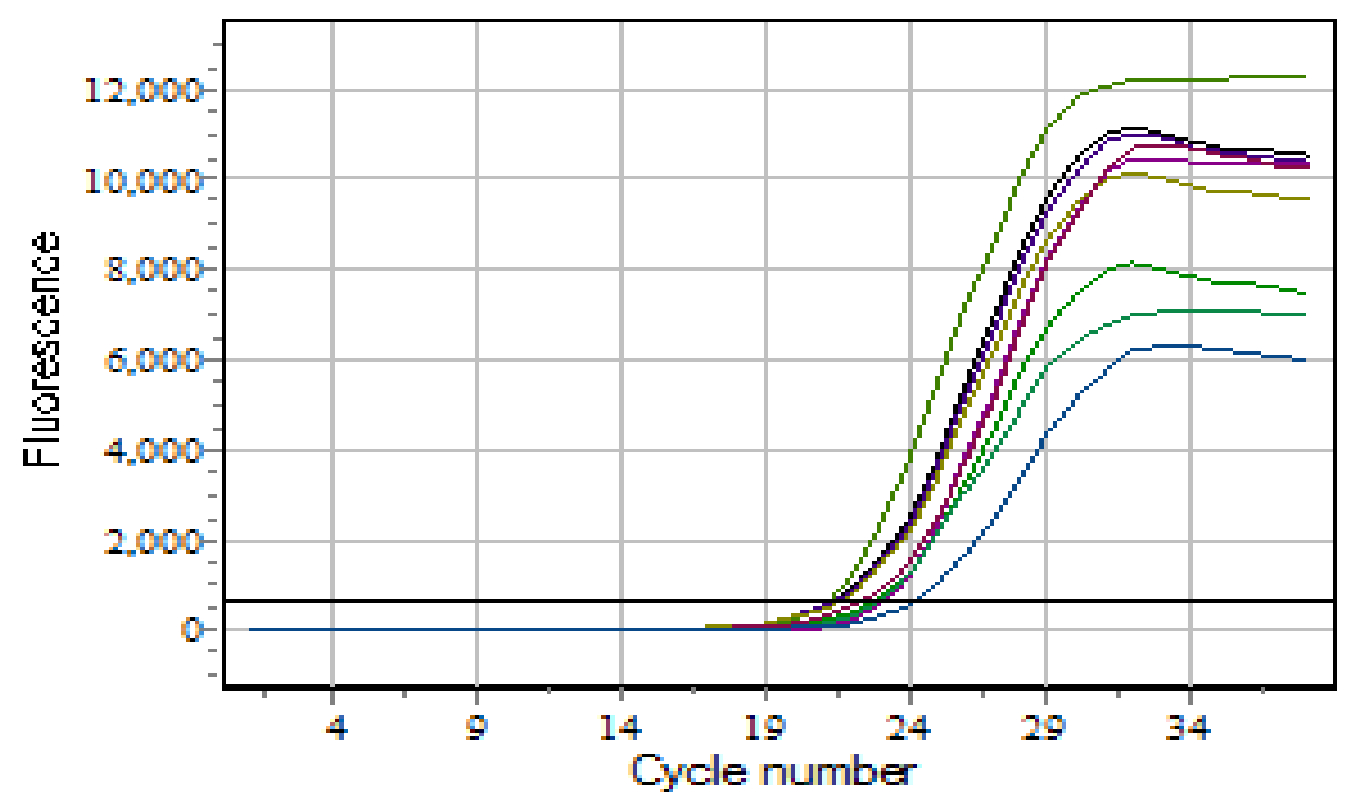

Figure 1:- resulted RT-PCR curves of Rubella and Toxoplasma detection.

The detection by using RT-PCR reported to be more sensitive than serological method as this method based on molecular detection of the active viruses. The results were summarized in table-3. 25 case subjects (with continues abortion) infected with rubella detected by ELISA were minimized to 20 sample after re-tested by RT-PCR and 29 control subjects minimized to 3 only this comparison were highly significant. While the infection with toxoplasma were recorded in 19 case subjects by ELISA minimized to 14 by RT-PCR and 11 control subjects to only 5 only this were also highly significant. The statistical test were done by ANOVA two way .

Table (3): The correlation betweenRubella and toxoplasmos

\begin{tabular}{|l|l|l|l|l|l|}
\hline \multirow{2}{*}{ Groups } & \multicolumn{2}{|l|}{ Case } & \multicolumn{2}{l|}{ Control } & \multirow{2}{*}{ p-value } \\
\cline { 2 - 6 } & RT-PCR & IgM & RT-PCR & IgM & \\
\hline Rubella & 20 & 25 & 3 & 29 & 0.001 \\
\hline Toxoplasma & 14 & 19 & 5 & 11 & 0.008 \\
\hline
\end{tabular}

The correlation betweenRubella and toxoplasmosis summarized in table--3 showed that 14 of the patients with Toxoplasmosis were also infected with Rubella and only 3 cases were infected with Rubella without the infection with toxoplasma. While the 20 subjects infected with rubella without toxoplasmosis infection and 21 . These data showed significantly $(\mathrm{p}=0.022)$ high odd ratio $=4.9$ (C.I. $=1.26$ to 19

Table (4): Risk for congenital rubella syndrome increases when infection occurs in early stages of pregnancy

\begin{tabular}{|c|c|c|c|c|c|c|}
\hline & & \multicolumn{2}{|c|}{ toxoplasmosis } & \multirow[b]{2}{*}{ p-value } & \multirow[b]{2}{*}{ odd } & \\
\hline & & infected & non-infected & & & \\
\hline \multirow{2}{*}{ rubella } & Infected & 14 & 6 & \multirow{2}{*}{0.022} & \multirow{2}{*}{4.9} & \multirow{2}{*}{1.26 to 19.13} \\
\hline & non-infected & 3 & 21 & & & \\
\hline
\end{tabular}

An estimated 5\% of couples attempting to have a baby experience recurrent pregnancy loss. Recurrent pregnancy loss is often defined as 3 or more consecutive miscarriages. There are many reasons a woman might miscarry, but in the past very few diagnoses were given or made known to the mother. Recent studies have shown that approximately 10 
to $15 \%$ of all first time pregnancies end in miscarriages. The studies also suggested that a similar miscarriage rate could be expected for future pregnancies. ${ }^{[10]}$. Jaslow CR et al (2010) ${ }^{[11]}$ and Rai R, Regan L.(2006) ${ }^{[12]}$ found there is significant relationship between history of miscarriage in the family and the studied group this is may be estimated to be due to the life style in the family and their health status these studies agreed with the current study.

Risk for congenital rubella syndrome increases when infection occurs in early stages of pregnancy. Specifically, the percentage of infants with congenital malformation exceeds $50 \%$ in cases of infection during the first trimester of pregnancy while the relative percentage is significantly reduced after the 20 th gestational week [13],[14],[15],[16],[17] . However, maternal viremia is not a proof of vertical transmission to the embryo, and fetal infection does not necessarily correspond to fetal damage. Namaei et al. reported that none of the infants of gravidas that received a measlesrubella vaccine at the interval between 3 months before and 3 months after conception appeared to experience viral consequences. This may be the reason why authors support detailed information provided to the mother in order to prevent unnecessary voluntary interruption of pregnancies ${ }^{[14,18]}$.

Prenatal diagnostic exploration should be recommended in case of positive PCR in order to detect the affected embryos, having more precise information concerning the fetal health status before the decision of pregnancy's termination ${ }^{[19,20,21,22]}$.Studies have demonstrated an association between viral load in amniotic fluid and the risk of a symptomatic infant, whereas further investigation with a noninvasive diagnostic procedure might postulate a method to evaluate potential fetal affection ${ }^{[22,23,24,25]}$.

Serological tests results by ELISA were not specific and may give false positive results that could be explain by chances of infection with other microorganism and that's also confirmed by the results asfew of the results obtained by ELISA were confirmed by $\mathrm{PCR}^{[26]}$. In addition, The results obtained in Al-Najaf indicates that the percentage of Rubella IgG was $49.12 \%$ and that revealed less than the result recorded by Lenochove in Turkey ${ }^{[27]}$.

Serological results obtained bybyThikra ${ }^{[28]}$. revealed 12 out of 57 patients were $\operatorname{IgM}$ and $\operatorname{IgG}$ for Rubella and after test them by PCR, only (50\%) of results were positive. And this result agreed with Nolan ${ }^{[29]}$. whose approved that out of 18 positive cases of Rubella by ELISA only 7 were positive by PCR. Our results revealed seropositive IgGfor Rubella and Cytomegalovirus percentagewere $49.12 \%$ and $70.2 \%$ respectively. After PCR test has done the results percentage has declined to $10.53 \%$ in Rubella virus, and this lead to real incidence of infection of this microorganism and reflect the false positivity of the routine ELISA test ${ }^{[30]}$. In addition, Toxoplasma gondii and Rubella both are considerednonactive infections in human being with continuous mini foci that may lead to immune response state. Antigenic diversity in viruses may add another explanation to give false positive results in ELISA ${ }^{[31]}$.

A small number of countries in Asia have a Rubellacontaining vaccine in their national immunization programs. At the moment, control of Rubella through vaccination has been achieved only in Japan, Taiwan and Singapore. Rubella therefore remains poorly controlled in many Asian countries. Data from 2009 shows that, in the Southeast Asian continent, the vaccination coverage rate is only (4\%) ${ }^{[32]}$, while in Iraq, the vaccination coverage was $67.6 \%$ and $88 \%$ as demonstrated in retrospective and prospective study respectively [33]. Various vaccine strategies have been used the world over to mitigate Rubella infections. As inoculation is now well received, vaccination programs strive to immunize all young people before the onset of puberty using a two-stage Rubella vaccination. In the event of a negative result, there is a chance of being immunized during the early stages of pregnancy which lead to specific IgM being detected ${ }^{[34]}$.

\section{Conclusion}

After representing these results we conclude that coinfection with both Rubella and Toxoplasma infection might increase the risk of miscarriageand we showed the sensitivity of molecular test and specially the RT-PCR is significantly sensitive than the serological test.

Conflict of Interest: There is no conflict of interest among the authors.

\section{Funding: Self}

Ethical Clearance: This study is ethically approved by the Institutional ethical Committee. 


\section{References}

[1] Kancherla V, Oakley Jr GP, Brent RL. Urgent global opportunities to prevent birth defects. InSeminars in Fetal and Neonatal Medicine 2014 Jun 1 (Vol. 19, No. 3, pp. 153-160). WB Saunders.

[2] Laharwal MA, Sarmast AH, Ramzan AU, Wani AA, Malik NK, Arif SH, Rizvi M. Epidemiology of the neural tube defects in Kashmir Valley. Surgical neurology international. 2016;7.

[3] Barron S. Anencephaly: an ongoing investigation in Washington state. AJN The American Journal of Nursing. 2016 Mar 1;116(3):60-6.

[4] Jones JL, Kruszon-Moran D, Wilson M, McQuillan G, Navin T, McAuley JB. Toxoplasma gondii infection in the United States: seroprevalence and risk factors. American journal of epidemiology. 2001 Aug 15;154(4):357-65.

[5] Ouermi D, Simpore J, Belem AM, Sanou DS, Karou DS, Ilboudo D, Bisseye C, Onadja SM, Pietra V, Pignatelli S, Gnoula C. Co-infection of Toxoplasma gondii with HBV in HIVinfected and uninfected pregnant women in Burkina Faso. Pakistan journal of biological sciences: PJBS. 2009 Sep;12(17):1188-93. [6] Hrnjaković-Cvjetković I, JerantPatić V, Cvjetković D, Mrdja E, Milosević V. Congenital toxoplasmosis. Medicinski pregled. 1998;51(3-4):140-5.

[7] Abu-Madi MA, Behnke JM, Dabritz HA. Toxoplasma gondii seropositivity and coinfection with TORCH pathogens in high-risk patients from Qatar. The American journal of tropical medicine and hygiene. $2010 \mathrm{Apr}$ 1;82(4):626-33.

[8] Okomo UA. Neonatal Infections; a hospitalbased study in The Gambia examining aetiology and associated maternal Colonisation (Doctoral dissertation, London School of Hygiene \& Tropical Medicine).

[9] Duszak RS. Congenital rubella syndromemajor review. Optometry-Journal of the American Optometric Association. 2009 Jan 1;80(1):36-43.

[10] Solomon B. Frequency of Chromosomal Abnormalities in Miscarriages and Other Associated Risk Factors (Doctoral dissertation,
Haramaya University). [11] Jaslow CR, Carney JL, Kutteh WH. Diagnostic factors identified in 1020 women with two versus three or more recurrent pregnancy losses. Fertility and sterility. 2010 Mar 1;93(4):1234-43.

[12] Marquard K, Westphal LM, Milki AA, Lathi RB. Etiology of recurrent pregnancy loss in women over the age of 35 years. Fertility and sterility. 2010 Sep 1;94(4):1473-7.

[13] De Santis M, Cavaliere AF, Straface G, Caruso A. Rubella infection in pregnancy. Reproductive Toxicology. 2006 May 1;21(4):390-8.

[14] Varella IS, Canti IC, Santos BR, Coppini AZ, Argondizzo LC, Tonin C, Wagner MB. Prevalence of acute toxoplasmosis infection among 41,112 pregnant women and the motherto-child transmission rate in a public hospital in South Brazil. Memorias do Instituto Oswaldo Cruz. 2009 Mar;104(2):383-8. [15] Peckham C. Congenital rubella in the United Kingdom before 1970: the prevaccine era. Clinical Infectious Diseases. 1985 Mar 1;7(Supplement_1):S11-6.

[16] Margioula-Siarkou C, Kalogiannidis I, Petousis S, Prapa S, Dagklis T, Mamopoulos A, Prapas $\mathrm{N}$, Rousso D. Cytomegalovirus, toxoplasma gondii and rubella vertical transmission rates according to mid-trimester amniocentesis: A retrospective study. International journal of preventive medicine. 2015;6. [17] Turbadkar D, Mathur M, Rele M. Seroprevalence of torch infection in bad obstetric history. Indian journal of medical microbiology. 2003 Apr 1;21(2):108.

[18] Namaei MH, Ziaee M, Naseh N. Congenital rubella syndrome in infants of women vaccinated during or just before pregnancy with measlesrubella vaccine. Indian Journal of Medical Research. 2008 Jun 1;127(6):551.

[19] Gouarin S, Gault E, Vabret A, Cointe D, Rozenberg F, Grangeot-Keros L, Barjot P, Garbarg-Chenon A, Lebon P, Freymuth F. Real-time PCR quantification of human cytomegalovirus DNA in amniotic fluid samples from mothers with primary infection. Journal of clinical microbiology. 2002 May 1;40(5):176772.

[20] Schlesinger Y. Routine screening for CMV in pregnancy: opening the pandora box?. The Israel Medical Association journal: IMAJ. 2007 May;9(5):395. 
[21] Revello MG, Gerna G. Diagnosis and management of human cytomegalovirus infection in the mother, fetus, and newborn infant. Clinical microbiology reviews. 2002 Oct 1;15(4):680-715.

[22] Guerra B, Lazzarotto T, Quarta S, Lanari M, Bovicelli L, Nicolosi A, Landini MP. Prenatal diagnosis of symptomatic congenital cytomegalovirus infection. American journal of obstetrics and gynecology. 2000 Aug 1;183(2):476-82.

[23] Lazzarotto T, Gabrielli L, Foschini MP, Lanari M, Guerra B, Eusebi V, Landini MP. Congenital cytomegalovirus infection in twin pregnancies: viral load in the amniotic fluid and pregnancy outcome. Pediatrics. 2003 Aug 1;112(2):e153-7.

[24] Gouarin S, Gault E, Vabret A, Cointe D, Rozenberg F, Grangeot-Keros L, Barjot P, Garbarg-Chenon A, Lebon P, Freymuth F. Real-time PCR quantification of human cytomegalovirus DNA in amniotic fluid samples from mothers with primary infection. Journal of clinical microbiology. 2002 May 1;40(5):176772.

[25] Gouarin S, Gault E, Vabret A, Cointe D, Rozenberg F, Grangeot-Keros L, Barjot P, Garbarg-Chenon A, Lebon P, Freymuth F. Real-time PCR quantification of human cytomegalovirus DNA in amniotic fluid samples from mothers with primary infection. Journal of clinical microbiology. 2002 May 1;40(5):176772.

[26] Flegr J, Lenochová P, Hodný Z, Vondrová M. Fatal attraction phenomenon in humans-cat odour attractiveness increased for Toxoplasmainfected men while decreased for infected women. PLoS neglected tropical diseases. 2011 Nov 8;5(11):e1389.
[27]

Bogoch II, Andrews JR, Speich B, Ame SM, Ali SM, Stothard JR, Utzinger J, Keiser J. Quantitative evaluation of a handheld light microscope for field diagnosis of soiltransmitted helminth infection. The American journal of tropical medicine and hygiene. 2014 Dec 3;91(6):1138-41.

[28] Mahmood TA, Sultan BA, Mohammed SN, AL-Hucheimi SN. Serological and Molecular Diagnosis of Rubella virus and Cytomegalovirus in aborted Patients in Al-Najaf province. kufa Journal for Nursing sciences. 2015;5(2):99-105.

[29] Nolan T, Hands RE, Bustin SA. Quantification of mRNA using real-time RT-PCR. Nature protocols. 2006 Aug;1(3):1559.

[30] Tamer GS, Dundar D, Caliskan E. Seroprevalence of Toxoplasma gondii, rubella and cytomegalovirus among pregnant women in western region of Turkey. Clinical and investigative medicine. 2009 Feb 1:E43-7.

[31] Tamer GS, Dundar D, Caliskan E. Seroprevalence of Toxoplasma gondii, rubella and cytomegalovirus among pregnant women in western region of Turkey. Clinical and investigative medicine. 2009 Feb 1:E43-7.

[32] Strebel PM, Gacic-Dobo M, Reef S, Cochi SL. Global use of rubella vaccines, 1980-2009. Journal of Infectious Diseases. 2011 Sep 1;204(suppl_2):S579-84.

[33] Al-Taie AA, Abdullah BA, Al-Attar MY. Molecular Diagnosis of TORCH Infection of Pregnant Women in Iraq. International Journal of Medical Sciences. 2019 Jan 1;2(1):58-68.

[34] Mauracher CA, Mitchell LA, Tingle AJ. Differential IgG avidity to rubella virus structural proteins. Journal of medical virology. 1992 Mar;36(3):202-8. 